\title{
The Effects of Industrial Environment, Innovation, and Government Policy on Business Performance (Evidences from Riau Songket Weaving Small Industry in Riau Province)
}

\author{
Samsir, Djumilah Hadiwidjojo, Armanu Thoyib ,Surachman \\ Faculty of Economics, University of Riau \\ Faculty of Economics and Business, University of Brawijaya
}

\begin{abstract}
This research aims to provide information about the effects of industrial environment on business performance, industrial environment on business performance with innovation as moderating variable, innovation on business performance and innovation on business performance with government policy as moderating variable. The population of this research is all small industries especially Tenun Songket Riau in Pekanbaru City, Bengkalis Sub District, and Siak Sub District, as many as 330 business units. Sampling method used is proportional sampling with total sample of 110 business units. Structural Equation Modeling (SEM) is used as data analysis and to be processed with AMOS 16 software. The findings of this study are as follows: (1) the more dynamic industrial environment results better business performance of small industry of Riau Songket Weaving; (2) the more dynamic industrial environment supports innovation capability and impacts better business performance of small industry of Riau Songket Weaving; (3) the higher innovation capability of the business results better business performance of small industry of Riau Songket Weaving, and (4) the higher innovation capability and to be supported by conducive government policy impacts better business performance of small industry of Riau Songket Weaving.
\end{abstract}

Keywords: Industrial Environment, Innovation, Government Policy, Business Performance.

\section{Introduction}

The role of small business in the economy of a country, including Indonesia, cannot be underestimated. According to Storey in Hill and McGowan (1999), small business is considered as an important determinant for most worlds' economies. In Indonesia, small business plays an important role when it is correlated with economic and social issues in the internal affairs country such as high levels of poverty, large numbers of unemployment, imbalance income distribution, uneven development process and urbanization problem with all its negative effects. The existence or development of small business is expected to contribute significantly to anticipation efforts of various problems.

The roles of small business in national economy according to statistics of small and medium enterprises in 2008 are as follows: First, the amount is very large and become the backbone of economy. In $2008,51.2$ million units $(99.91 \%)$ are small enterprises, 39 thousand units $(0.08 \%)$ are medium, and 4.3 thousand $(0.01 \%)$ are large. Second, it has created vast employment opportunities for the society. In 2008, small enterprises can create jobs for 87.6 million people $(93.56 \%), 3.2$ million people $(3.48 \%)$ are absorbed by the medium, and only 2.7 million people $(2.96 \%)$ are absorbed by large enterprises. Third, it has contributed in the establishment of national production. In 2008, the role of small enterprises to national GDP in current prices is IDR 1,978.58 billion (42.13\%), medium, it is IDR 630.78 billion (13.43\%), and large enterprises it is IDR 2,087.12 trillion (44.44\%). Furthermore, the contribution to national GDP at constant price in 2000, the role of small enterprises is amounted to IDR 871.98 trillion (42.65\%), medium enterprises is IDR 293.27 billion (14.68\%), and the contribution of large enterprise is IDR 832.47 billion (41.67\%).

Although small business in Indonesia economy plays as central role, but it still faces various problems. According to Urata (2000), the problems faced by small enterprises can be grouped into two: financial issues and non-financial issues (organizational management). Issues included financial issues are: (1) Mismatching between fund availability and fund easiness that can be accessed by small enterprises, (2) The lack of systematic approaches to small enterprises financing, (3) High transaction costs caused by credit procedures are quite complicated so it takes a lot of time while the disbursed loan amount is very small, (4) Lack of access to formal sources of funds, which is caused either by the absence of banks in rural or the unavailability of adequate information, (5) High interest loans for investment and working capital, (6) The low number of small enterprises that are not bankable, either due to less transparent financial management or managerial and financial incapability.

While the issues that are included in non-financial issues (organizational management) are: (1) The lack of knowledge on production technology and quality control due to few opportunity to keep abreast of the 
technology and the lack of education and training, (2) The lack of marketing knowledge, which is caused by limited information that can be reached by small enterprises in the market, and limited small enterprises to provide products/ services in accordance with market expectation, (3) Limited skilled and creative human resources, and (4) The lack of understanding on accounting and finances for small business.

Kuncoro (2006) states that small business problems can be classified into two that are internal and external problems. Internal problems faced by small enterprises are low quality of human resources such as the lack of skilled human resources and entrepreneurial spirit, low mastery of technology as well as management and market information. This Human Resource problem will affect the low levels of productivity and management arrangements quality, while external problems faced by small enterprises in general are: (1) unfinished business in handling problems, legality entities and smooth licensing procedures, fair competition implementation, arranging business location and regional autonomy, especially the willingness to empowerment small enterprises, (2) slow speed of recovery in macro economic conditions due to the increase in fuel and other energy greatly affecting small business operations, (3) limited availability of products and quality in particular financial institutions especially investment loans, (4) limited availability and of business development services quality for small enterprises, and (5) the lack of financial resources for small enterprises.

The development of dynamic business environment affects every company, whether large, medium or small. Competitive advantage factors that should owned by each company to be competitive in the market in particular are technology proficiency, human resources with high quality and work ethic, creativity and innovation, the high quality of goods produced, and how to face appropriately (efficient and effective) the changing in industrial environment.

Some researchers suggest that environment plays role in business development. The main key for the success of companies in tight competition is their ability. The company should be able to cope with and adapt to the changing environmental conditions that always fluctuate (Hopkins, 1997; Miller and Cardinal, 1994). Increasing changes in business environment, market and global competition, reinforced by rapid technological change and the growth of competitiveness encouraged many companies to improve or maintain performance to keep them going concern. The environment includes a number of external factors that can emerge opportunities or threats to the company that affect its competitive advantage.

Many studies have been conducted to prove whether environment has an effect on organization performance, but there are many research results give different results. The results from Lou (1999), Baum et al. (2001), Yonggui et al. (2003), Herri et al. (2003), Child (1997), Hamel and Prahalad (1994), Lampkin and Dess (1996), Pelham (1999) and Suhardhika (2011) show that environment gives an effect on business performance, while some studies have shown the inexistence of strong relationship between environment and business performance. Research results by Rivard et al. (2005), Yurniwati (2005), Hakim (2007), Suci (2008), and Rofiaty (2010) state that there is no significant effect between the environment and business performance.

The existence of some differences in results of industrial environment with performance, according to by Han et al. (1998), is because there is missing variable chain between industrial environment and performance, so Han et al. (1998) emphasize that further research is necessary regarding the role of innovation in order to produce excellent performance. Furthermore, from the perspective of resource-based view, it emphasizes the importance of resources and the ability in developing competitive advantage. Innovation is the key that leads to competitive advantage, therefore innovation and its relationship with resources and capabilities need further study (Thong, 1999; Hadjimanolis \& Dickson, 2000).

Based on the research gaps and recommendations from Han et al. (1998), innovation is used in this study as mediating variable that links between industrial environment and business performance. The role of innovation as mediating variable may explain the effect of industrial environment on business performance that is varied and has not been widely explored. In contrast to previous studies, which generally only examined the direct effect on industrial environment on business performance and emerged the controversy about the results of industrial environment on business performance, the empirical model in this study contributes to the development of management strategy knowledge since it seeks to explain the effect of industrial environment on business performance and industrial environment on business performance which is mediated by innovation.

Dynamic business environment reinforced by rapid technological change and growing competitiveness encourage many companies to be more innovative in all business activities (Weerawardena, 2003). In the perspective of strategic management, environment is important contextual factors that have an impact on innovation and competitive advantage sustainability. Research conducted Tidd (2001) used the research literature stating that there is complexity and uncertainty of environment effect on innovation and organization performance. The results have also shown the importance of innovation, the company competing in global industry, which invests in innovation, will get a higher profit (Hitt et al., 2002). Innovation has considerable impacts on corporate performance by generating better market position that enhance competitive advantage and superior performance (Walker, 2004). 
More specific, the study by Agarwal et al. (2003), David et al. (2007), Rhee et al. (2010), Gunday et al. (2011), Rosenbusch et al. (2011), Geroski et al. (1993), Rofiaty (2010), and Hidayatullah (2011) prove that there is a positive influence of innovation on business performance. Foray et al. (2007) and Yasuda (2005) show that spending on Research and Development has a positive impact on corporate growth. Adamou and Sasidharan (2007) find that companies with high ratio of intensity of Research and Development spending will generate faster sales growth.

However, several other studies give different results as Robson and Bennett (2000), find no evidence of profitability growth for small corporate doing innovation in the UK. Loof and Heshmati (2006) also find no significant impact on Research and Development spending on corporate growth. Kirchoff et al. (2002) and Oliveira and Fortunato (2005) figure out that physical investment has much higher impact on firm growth compared to Research and Development investment. Bottazzi et al. (2001) find that innovation does not influence the corporate sales growth. Mavondo et al. (2005) argue that product innovation does not have any significant impacts on financial performance. Darroch (2005) finds that innovation has no effect on performance as measured by both financial and non-financial performance on market share and sales growth.

Several empirical studies on the role of government policy on small business performance improvement such as research carried out by Antonio, Isabel and Reguel (2003) finds that training has a significant impact on performance improvement of the corporate. Thurik and Wennekers (2004) in their study conclude that government policy in controlling the economy by involving technology and consumer stability will improve business performance. Rasiah (2002) mentions that autonomic government that is proactive in supporting the development of small and medium enterprises by giving public training and market information. Sullivan (2002) mentions that the role of local government is able to promote economic development by providing subsidies. Abdullah (1999), Dimitris et al. (2004) find out that capital subsidy has significant effect on four dimensions, which are efficiency, profitability, capital structure and productivity growth of corporate. Stuart (2000) mentions that technological cooperation between large and small companies to attract customers, in turn can increase sales and product innovation.

The conclusion of this description is that government role is needed to realize the innovative behavior of small enterprises, particularly in the form of assistance such as training, technology, market information and funds. Therefore, it is necessary to conduct further research in order to explain the causal relationship between innovation and performance and try to develop empirical research model by involving government policy as a moderating variable between innovation and business performance in Riau songket weaving small industry. Government policy as a moderating variable theoretically aims to realize creativity and innovative behavior that should be helped and supported by the government in the form of human resources quality such as in training, supporting facilities, and information since most small industries have the weakness of the lack of resources including financial resources, training and human resource development.

The purposes of this study are to examine the effects of (1) industrial environment on business performance, 2) industrial environment on business performance mediated by innovation, 3) innovation on business performance, and 4) innovation on business performance of Riau songket small industry moderated by government policy.

\section{Literature Review}

Here below are some literature reviews concerning with the study variables and previous research.

\section{Industry Environment}

Environment includes external factors outside the companies that emerge the opportunities or threats for them. Environment will affect companies' competitive advantage. Thompson et al. (2006) state that environment relevant or potentially relating to the objective achievement of industrial environment include: (1) customers (both distributors and users), (2) suppliers of materials, labor, capital, equipment, and work space, (3) competitors (both ad markets resources; and (4) regulatory groups, including governmental agencies, unions, and inter-firm associations. Jauch and Glueck (1998) in their theory concept classifies industrial environment into customers, suppliers and competitors (new entrants and substitute products). The inability to respond to external changes through internal strength will make the company suffered shock (Pearce et al., 2003).

Environmental uncertainty is the result of complexity and diversity of many environmental factors that affect the business rate of change or dynamism experienced in environmental conditions (Hatch and Cunliff, 2006). Complexity describes the deployment of various environmental forces in affecting companies (Boyd and Elliot, 1998 and Short et al., 2007). The complexity of the environment is characterized by environmental factors heterogeneity and diversity. Heterogeneity concerns on how much influence of each factor to the success of company, while the diversity concerns on the difference between the environmental factors needed to be addressed by company (Dess and Beard, 1984; Lou and Peng, 1999). 
Empirical research on the relationship of industrial environment on competitive advantage has been widely applied. When a company has to deal with hostility environment, as in the high technology sector, it will encourage companies to obtain greater performance. Meanwhile, in a benign environment, conservative strategic orientation is suitable for improving small business performance (Covin and Slevin, 1989). Morgan (1997 in Gana, 2011) believes that more innovative organization depends on the strategy, technology, human/ cultural, managerial and environmental. It can be concluded that organization cannot be separated from environment, so that is common to find that innovation is driven by environmental factor. According to Lou (1999), saying that environment complexity and dynamics will affect innovation of an industry. Besides affecting innovation, environment also affects the success of business. Lampkin and Dess (1996) mention that business performance is independently affected by environmental factors such as dynamism, munificence, complexity, and industry characteristics.

Researchers from various disciplines such as government, marketing, and strategy correlate environment with stakeholder groups both internal and external. Shareholder theory starts from Agency Theory by Berley and Means (1932), Jensen and Meckling (1976) cited in Freeman (1994) and the development of this theory is called as stakeholder theory. Freeman (1984) defines stakeholders as "any group or individual who can influence or be influenced by corporate goals achievement". Donaldson and Preston (1995) and Deshpande and Farey (1999) convey that a firm with higher orientation and serving the stakeholders' interests will perform better and be able to maximize the company's assets and benefit collectively to all stakeholders. From the above it can be concluded that the company should pay attention to the industrial environment by building partnership with the stakeholders so that it affects the company's capabilities in doing innovation to improve the performance.

\section{Innovation}

Innovation is the part of human struggle in maintaining identity or life survival. So far, humans had managed to create new solutions, even though some then turned out to be threats (Fonseca, 2002). Innovation can be seen from its definitions, dimensions and measurements. There are some definitions of innovation found in the literature. Schumpeter (1934) in Gana, 2011) mentions five possible types of innovation which are (1) new product introduction or qualitative change in existing product, (ii) the process of innovation for industry, (iii) new market opening, (iv) new sources development of raw material supply or other inputs, and (v) changes in industry organizations.

Robbins (2002) focuses on three main issues that are (1) new idea as a process to think in observing a phenomenon that is happening, this new idea may be the discovery of ideas, thoughts, systems, the possibility of crystallized ideas, (2) products and services as the result of further steps that is followed up by new ideas with various activities, studies, researches and experiments bearing more concrete concept in the form of products and services that are ready to be developed and implemented, (3) improving efforts as the systematic attempt to make perfection and make improvements of continuous innovation so that the result of innovation can be useful and give advantages. Roger (1995) mentions that innovation is an idea, thought, practice or object that are recognized and accepted as a new thing by a person or group to be adopted.

From resources point of view, innovation can be classified on the innovation that begins with the emergence of organization (emergent) adopting from other companies (imported) or is driven from outside the organization (imposed). Meanwhile, OECD (2007) conveys that the implementation of innovation is new or significantly improved products (goods and services), or process, new marketing method, or new organizational method in business practices, organization or workplace. Four types of innovation classified based on the definitions are (i) product innovation, (ii) innovation process, (iii) marketing innovation, and (iv) organization innovation.

Prather and Grudy (cited in Ceramy, 2001) state that innovation is as the implementation of business ideas that comes from structure and culture support, and organizational creativity. Thompson (in Hurley \& Hult, 1998) provides a definition of innovation classically i.e. the implementation of new ideas, products or processes. Amabile et al. (1996) (in Hurley and Hult, 1998) define innovation as successful implementation of a creative idea in an organization. Hurly \& Hult (1998), Rhee et al. (2010) believe that innovation is more on an aspect of organization culture that reflects the openness level to new ideas, rewards for employees to new ideas, learning ability, ideas implementation into real thing. From the results above, it can be concluded that innovation also significantly affects organization performance.

Darroch (2005) considers that innovation is an output from organization that utilizes input power source of its knowledge, information, and experience perceived among most employees and the impact on financial performance improvement. Darroch (2005) states that more innovative company is the company that is able to acquire, deploy, and be responsiveness to knowledge. 


\section{Government Policy}

The development of Micro and Small Enterprises (MSEs) in Indonesia is one of the priorities in national economic development. This is because besides the business as the backbone of the economic system of democracy, it does not only intend to reduce disparity problem among income groups and enterprises, or poverty alleviation and employment absorption. Moreover, the development is able to expand its economic basis and can provide a significant contribution to accelerate structural changes that are increasing regional economy and national economy resilience.

These conditions and facts is in line with the results of empirical research conducted by Demirbag et al. (2006) that conclude that the success of small and medium enterprises has a direct impact on economic development in both developed and developing countries. The role played by this sector is expected to continue with government and other parties ways to have clear references about the factors that affect business performance improvement.

Research conducted by Rasiah (2002) which compares the success of small and medium companies in machinery tool industry conducted in two cities of Penang and Kelang Valley shows the results proving that Penang has managed to develop small and medium industries while not in Kelang Valley. Kelang Valley City holds different government status with Penang. Autonomy Penang government has been proactive in supporting the development of small and medium industries in the form of public training and providing market information.

Sullivan (2002) states that the role of local government to promote economic development by providing subsidies to companies and reduce uncertainty risk. The survey found that majority firms obtaining subsidies and risk control may get positive result and a lot of them tend to hire employees, which is useful in business development and regulation aggressively. Research by Dimitris (2004) proves that capital significantly influences the four dimensions that are efficiency, profitability, capital structure and firm productivity growth. Likewise, Fredrick (2000) also believes that subsidy may affect the increase of company growth. Stuart (2000) finds out that cooperation can build public trust on products and services produced in order to ease the companies to attract customers and ultimately increase their sales and product innovations.

\section{Business Performance}

Business performance is extremely important in ensuring business sustainability. Performance is referring to the achievement or performance level of company within a certain period of time. Business performance other than as a reflection of the success or failure of a company, can also describe as the results achieved from the implementation of work functions or activities series within a certain period (Bernardin and Russell 1993). The performance can be seen from the company's sales, profitability, return on capital, turnover rate, and market share grabbed by the company (Jauch and Glueck, 1988).

Verreynne (2006) measures the performance of small-scale enterprises (SMEs) by using measures of financial performance scale developed from Covin and Slevin (1989), and Gupta and Govindarajan (1984) with the aim to describe the limitation of financial data in the performance measurements of small and medium enterprises (SMEs). Gupta and Govindarajan (1984) includes an assessment based on a Likert scale of ten financial measure covering sales levels, growth rates, return on equity, gross profit margin, net operating income, earnings ratios, return on capital, financing ability from its profits, and overall performance. According to Dess and Robinson (1984), the method of Gupta and Govindarajan apparently has high reliability and validity.

Machin and Stewart (1990) state that there is no consensus about the most appropriate performance measures in a study, and objective measures that have been used recently. Camison in Sanchez \& Marin (2005) measured small and medium enterprises performance by referring to three aspects, which are profitability, productivity, and market. While Lee and Tsang (2001) used business performance represented by venture growth covering sales growth, asset growth, and corporate profits growth. Studies of small and medium business performance measurement typically use mixed approaches (financial and non-financial), but difficulties arise when the managers of small and medium business owners are not willing to provide information or mind to share financial performance data (Beal, 2000). In anticipating the unavailability of real performance data, it is possible to use perception approach of the owners or managers of small and medium enterprises (Dess \& Beard, 1984).

Based on the description above, due to the limitations of small industrial in putting some accounts then in measuring business performance using the perception of owner or manager by using performance measurement of Lee \& Tsang (2001) and Suci (2008) that use business performance represented by venture growth consisting of sales growth, asset growth, and corporate profits growth. 


\section{Conceptual Framework and Research Hypothesis}

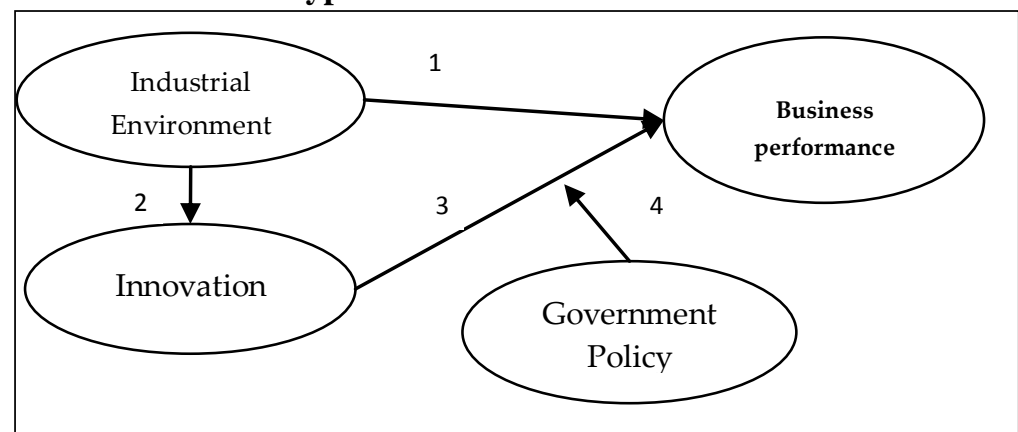

Figure 1. Research Conceptual Framework

Sources: 1). Baum, et al. (2001), Yonggui, et al. (2003), and Suhardhika (2011).

2). Weerawardena, 2003, Luo (1999), Tidd (2001), and Rofiaty (2010)

3). Rhee, J, et al. (2009), Rosenbusch, N, et al. (2011), and Gunday et al. (2011).

4). Rasiah (2002), Sullivan (2002), and Antonio, et al. (2003)

\section{Methodology}

The approach used in this study is quantitative approach (positivism). This study also adds some explanatory information from some respondents to supplement the results obtained from quantitative approach. The population is the whole business of songket weaving small industry owned and managed by the owners who are in Pekanbaru City, Bengkalis District, and Siak District as many as 330 units. Sample size determination is based on modeling assumptions of Structural Equation Modeling (SEM) that is between 100200 respondents (Ferdinand, 2006; Solimun, 2002). The sample size in this study of 100 small and plus $10 \%$ is to anticipate if there are some data that cannot be analyzed. From a sample of 110 enterprises, 110 respondents of business owner/ manager are also taken. The sample size of business for each city and county is chosen by using proportional sampling technique.

In the questionnaire, the indicators are set by reflecting latent variables and question items intended are arranged as closed questions with Likert scale of five. Validity and reliability tests are conducted to determine whether the number of indicators used is able to measure accurately latent variables and also to figure out whether the measurement showing consistent results when it is used repeatedly. Structural Equation Modeling (SEM) is used in testing the model proposed, which enables to analyze the series of relationships simultaneously (Hair et al., 2006).

\section{Structural Equation Modeling Assumption Test}

\section{Result and Discussion}

Normality assumption test, the multivariate test results show the data are normally distributed (because value c.r $=-0950$; $\mathrm{z}$ value for $\alpha=0.05$ is 1.96 , so c.r $<\mathrm{z}$ ). Outliers, based on examination using Mahalanobis distance statistically show that there are some outliers multivariate observations (case number 52, 31, and 84). According to Ferdinand (2002), in the analysis of the study, when there is no particular reason to exclude cases indicating outliner, then the case should still be included in subsequent analysis. From linearity test, it shows that all relationships between variables relationships in the structural model are linear, so the linearity assumption in SEM analysis is fulfilled.

\section{Structural Equation Modeling (SEM) Analysis}

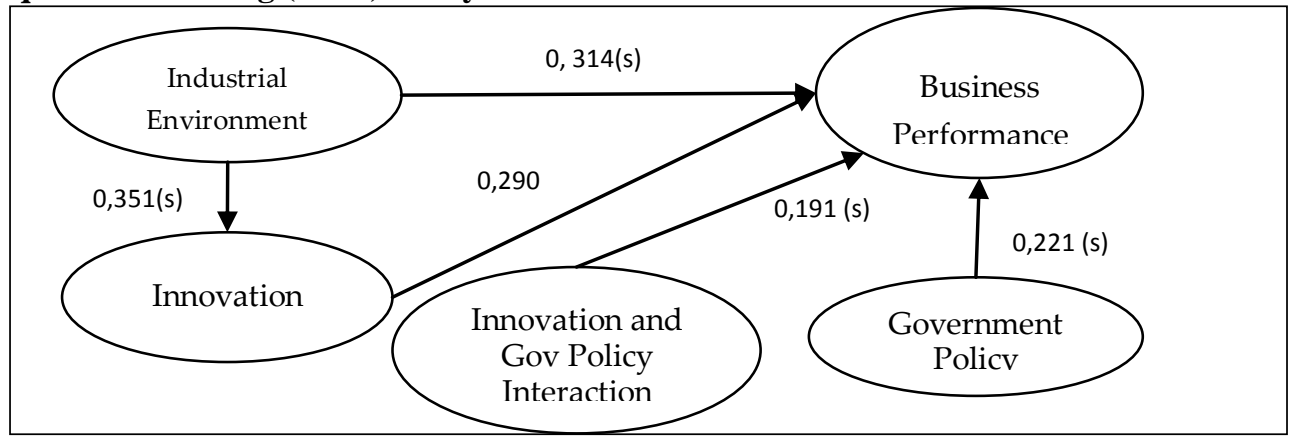

Figure 2. Structural Model Calculations Result 


\section{Hypothesis Testing}

Table 1. Direct and Indirect Effect Testing

\begin{tabular}{|c|c|c|c|c|c|c|c|}
\hline \multirow{3}{*}{$\begin{array}{l}\text { Independent } \\
\text { Variable }\end{array}$} & \multirow{3}{*}{$\begin{array}{l}\text { Dependent } \\
\text { Variable }\end{array}$} & \multicolumn{6}{|c|}{ Path Coefficient } \\
\hline & & \multicolumn{3}{|c|}{ Direct Effect } & \multicolumn{3}{|c|}{ Indirect Effect } \\
\hline & & $\begin{array}{c}\text { Standar- } \\
\text { dize }\end{array}$ & $P$-value & Description & $\begin{array}{c}\text { Intervening } \\
\text { Variable }\end{array}$ & $\begin{array}{l}\text { Standar- } \\
\text { dize }\end{array}$ & $\begin{array}{c}\text { Descriptio } \\
\mathrm{n}\end{array}$ \\
\hline $\begin{array}{l}\text { Industrial } \\
\text { Environment }\end{array}$ & $\begin{array}{l}\text { Business } \\
\text { Performance }\end{array}$ & 0.314 & 0.030 & Sig & Innovation & 0.154 & Sig \\
\hline Innovation & $\begin{array}{l}\text { Business } \\
\text { Performance }\end{array}$ & 0.290 & 0.038 & Sig & - & - & - \\
\hline $\begin{array}{l}\text { Government } \\
\text { Policy }\end{array}$ & $\begin{array}{l}\text { Business } \\
\text { Performance }\end{array}$ & 0.221 & 0.037 & Sig & - & - & - \\
\hline Interaction & $\begin{array}{l}\text { Business } \\
\text { Performance }\end{array}$ & 0.191 & $<0.001$ & Sig & - & - & - \\
\hline $\begin{array}{l}\text { Industrial } \\
\text { Environment }\end{array}$ & Innovation & 0.531 & $<0.001$ & Sig & - & - & - \\
\hline
\end{tabular}

Sources: Appendix 4, processed.

The first hypothesis has been proven showing that industrial environment has a positive and significant effect on business performance, this is shown by standardized values of positive 0.314 with p_value $=0.030$. This result means that the more dynamic industrial environment may result better performance of Riau songket weaving small industry.

The second hypothesis of indirect effect of industrial environment on business performance mediated by innovation is positive and significant. Innovation is proven mediating indirect effect of industrial environment on business performance with path coefficients of 0.154 . It means that innovation power driven by dynamic industrial environment is able to improve business performance. However, innovation is not as key mediator in indirect effects of industrial environment on business performance because innovation partially mediates this relation (partial mediation). This study further finds path coefficient on direct effect of industrial environment on business performance is greater than path coefficient on indirect effect, but the total effect would be greater in improving business performance. Thus, it can be concluded that the more dynamic industrial environment improving innovation results higher business performance of small enterprises of Riau songket weaving small industry.

The third hypothesis stating that innovation has a positive and significant effect on business performance is acceptable. The standardized value appeared as 0.290 is positive with $p_{\text {_value }}=0.038$. This indicates that higher innovation impacts on better business performance of Riau songket weaving small industry.

The fourth hypothesis which states that innovation has an effect on performance moderating by government policy is proven with positive and significant results. It shows standardized value of 0.191 with $p_{\text {_value }}=<0.001$. The effect of government policy and interaction on business performance is positive and significant, hence it can be concluded that government policy is as quasi moderation. On the other hand, the effect of innovation on business performance is also significantly positive, the higher innovation power and with support from favorable government policies gives impact on higher performance of Riau songket weaving small industry.

\section{The Effect of Industrial Environment on Business Performance}

Based on path coefficients analysis, the correlation of industrial environment on songket weaving business performance is positive and significant. This finding can be interpreted that industrial environment (bargaining power of customers, bargaining power of suppliers, and the condition of competition level) that changes faster will help in improving business performance. So, in essence, the desire of customer/ buyer change quickly (competitive price, quality, the availability of goods and services) to encourage the songket weaving small industry to proactively meet the desire. While from the supplier, its stronger position will encourage the songket weaving business to cooperate with suppliers or make purchases together so that the price of raw materials bought will be cheaper, the quality and availability of raw materials will be more guaranteed. The pressure grows stronger from competitors; it will push the capacity of songket weaving small industry in anticipating quality, price, service and offsetting promotion done by competitors in order to increase sales.

Several previous studies examining the effect of industrial environment on the performance does not provide significant results for several reasons. For example, Suci (2008) and Rofiaty (2010) state that small enterprises do less creative in breaking through innovation. Suhardhika (2011) mentions that small and medium enterprises are still weak in capturing and anticipating the changes that occur in business environment. The results for Riau songket weaving businesses prove that dynamic environment reflected by bargaining power of 
customers or buyers, bargaining power of suppliers, and competition level turns to increase their business performance when it is responded proactively and innovatively by Riau songket weaving business.

\section{The Effect of Industrial Environment on Business Performance Mediated by Innovation}

This finding proves that industrial environment is able to explain business performance, either directly affected or mediated by innovation. In this mediation model, innovation partially mediates indirect effect of industrial environment on business performance of Riau songket weaving industry. This study further finds path coefficient on direct effect of industrial environment on business performance is greater when it is compared to path coefficient on indirect effect, yet the total effect would be greater in improving business performance. This finding indicates that innovation is as an important mediator because it gives greater effect on business performance improvement compared to the direct effect of industrial environment on business performance.

This finding also provides evidence that competitive advantage can be built and created from how songket weaving small industry responds proactively to dynamic change of industrial environment changes by enhancing innovation, which in turn it can improve business performance. It provides an overview that innovation enhancement through the development of innovative ideas, reward for innovative ideas and implementation of innovative ideas are driven by changes in dynamic industry environment represented by bargaining power of customers or buyers, bargaining power of suppliers, and increasing levels of competition.

Several previous studies examining the effect of industrial environment on performance have nonsignificant results (Suci, 2008; Rofiaty, 2010; Suhardhika, 2011). The strength of influence between those variables can be explained by the ability to anticipate further changes whether small enterprises are able to follow up with proactive attitudes and innovative actions.

\section{The Effect of Innovation on Business Performance}

The analysis result of innovation effect on performance shows that innovation has a positive role in improving business performance in which higher innovation gives impact on higher performance of Riau songket weaving small industry. Furthermore, these results can be interpreted that the owners of songket weaving small industry are able to develop innovative ideas, respect the innovation ideas and do better implementation of innovative ideas will be able to improve their business performance. These abilities of will certainly have an impact on the fulfillment of customers or buyers' needs and wants in good quantity and quality, competitive price, punctuality and satisfying service and in the turn, it is increasing sales and gaining profit.

The ability of songket weaving small industry in fulfilling the needs and wants of customers or buyers cannot be separated from their ability in building networks with raw materials suppliers so raw materials in right quantities, best quality, punctuality and guarantee of raw materials can be completed. In other words, the owners of songket weaving small industry must build better supply chain with both upstream (suppliers) and downstream (consumer) so that business performance will increase.

Empirical facts occurring in the field suggest that the indicators used to measure innovation demonstrated low results, as well as business performance. Based on the indicators of innovation, developing innovative ideas, rewarding for the ideas of innovation and implementing innovative ideas, they demonstrate that songket weaving small industry has not implemented optimally innovation power in order to increase business performance.

\section{The Effect of Innovation on Business Performance Moderated by Government Policy}

An important finding in this study is that government policy acts as quasi moderation. Based on hypothesis testing, besides government policy is to strengthen innovation influence on business performance, government policy also directly affects business performance. Government policy consisting of exercise frequency, the easiness of capital access, and cooperation is external factors when it interacts with innovation power consisting of the development of innovation ideas, the reward to innovation ideas, and the implementation of innovative ideas will be able to improve business performance of songket weaving small industry.

Government policy that directly affects business performance is an interesting finding from this study. This phenomenon can be interpreted that the role of government through training programs, easiness to capital access, and partnerships is a very important factor in improving business performance in songket weaving small industry. From these two relationships, it is clearly concluded that government policy influence is stronger than the interaction of innovation and government policy on business performance, so that government policy can act as an independent variable on business performance. 


\section{Conclusion}

\section{Conclusion and Recommendation}

The dynamisms of industry environment that are bargaining power of customers/ buyers, suppliers power and competition intention can improve business performance by acting proactively to the dynamisms of industrial environment.

An increasing dynamic industrial environment will encourage the thoughts to be more creative and innovative to produce higher quality products, more efficient, and punctual in fact can improve business performance. Innovation power will determine successful business performance of songket weaving small industry. The low sales growth, profit growth, asset growth, and especially the lack of capability development are mostly because of innovation ideas, rewards, and ideas implementation. The improvement of small business performance cannot be separated from the role of government to small enterprises through various policies that are implemented in the form of training appropriate for the needs of small enterprises, providing access to capital and developing business partnerships.

Overall, it can be concluded that in order to improve the performance of small enterprises are determined by external and internal factors. The main key internal factor is the innovation as the essence of entrepreneurship. So the dynamisms of industrial environment are realized with the bargaining power of customers, bargaining power of suppliers, and stronger competition level should be responded by addressing more creative and innovative thinking or enhancing entrepreneurial spirit.

\section{Suggestion}

\section{Advice for Business Owners and Government}

The owners of Riau songket weaving small industry in improving business performance should respond to changes in industrial environment by looking for new ideas and practicing more effectively and efficiently, in cooperation with stakeholders such as customers, suppliers, and entrepreneurs.

Local government is necessary in doing education and training to achieve innovation by providing materials in accordance with weaving industry which includes design, quality standards, production cost determination, the use of information technology, websites for promotion and transaction. Government is as an innovator, initiator, facilitator to build weaving industry partnership with state-owned, private enterprises and other parties that have business relationships between big business and weaving industry, provide credits without any collateral, ease small enterprises in accessing capital resources.

\section{Limitations and Future Research}

This study has not used control variables such as age, the education background of owner/ entrepreneur, local culture in examining the role of industrial environment on innovation and performance that are expected to be able to distinguish the research results. Future research is suggested to use control variables to enrich the researches in entrepreneurship field. 